\title{
Novas proposições sobre Teoria da Comunicação
}

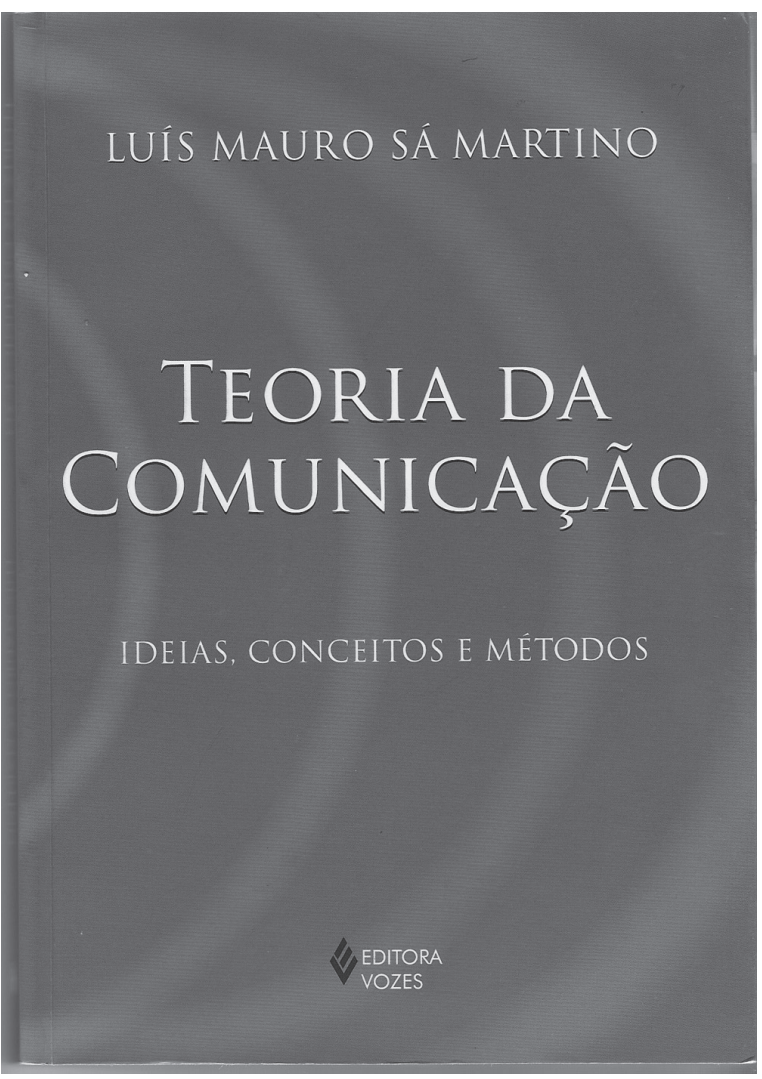

MARTINO, Luís Mauro Sá. Teoria da comunicação: ideias, conceitos e métodos. Petrópolis: Vozes, p. 286, 2009.
Débora Thayane de Oliveira Lapa Gadret Mestranda em Comunicacão e Informação pela UFRGS/RS/BR deboralapa@hotmail.com

\section{Cristóvão Domingos de Almeida}

Doutorando em Comunicacã̃o e Informação pela UFRGS/JRS/BR cristovaoalmeida@gmail.com
O estudo da comunicação caracteriza-se por sua imbricação com diferentes disciplinas, o que demanda do estudante da área e do pesquisador uma visão abrangente do conhecimento científico produzido neste campo. Tal complexidade pode provocar desorientação na medida em que se tenta organizar as múltiplas teorias utilizadas na pesquisa acadêmica. Luís Mauro Sá Martino consegue, em Teoria da comunicação: ideias, conceitos e métodos, apresentar um panorama da disciplina de maneira clara e didática, em uma tessitura que possibilita ao leitor construir conhecimento à medida que adentra no texto.

Logo de início, Martino, baseado na produção brasileira e anglo-saxônica na área, expõe que não há consenso entre autores sobre o que é teoria da comunicação. Para encontrar os pontos de convergência, dá a conhecer as fronteiras e definições da comunicação como disciplina plural e define, em linhas gerais, que "uma teoria é um conjunto de conceitos criados a partir da observação e estudo sistemático de um tema e que, aplicado, pode explicar alguns aspectos da realidade" (p. 11). Assim,

\section{falar em teoria da comunicação é pensar a realidade a partir das relações de comunicação ou, ainda, como as relações de comunicação podem se articular com as relações sociais. \\ O livro é dividido em quatro seções: A produção da comunicação, Do texto ao contexto, Estudos de recepção, e Moderno/Pós-Moderno. Cada uma é subdivida em capítulos que, "no intuito de apresentar o cenário, indicando as trilhas para outros inícios" (p. 14), trazem indicações bibliográficas dos textos de origem dos conceitos apresentados. Assim, dentro de um mesmo capítulo - no qual o autor apresenta múltiplas ideias -, logo após a apresentação inicial ele}


indica sistematicamente uma leitura evitando, desse modo, extensas listas bibliográficas e auxiliando o leitor na busca de um conhecimento mais aprofundado dos diferentes conceitos.

Outro ponto relevante são os exemplos que auxiliam na compreensão dos conceitos. Das Spice Girls, passando pelo Big Brother até a cobertura da CNN, essas ilustrações servem, mesmo para aqueles que não compartilham do repertório do autor, como sucinta explicação da temática em debate, deixando o texto mais claro e acessível.

\section{Cada capífulo, ainda que possa ser lido de maneira independenfe, constrói conceitos a partir das ideias apresentadas anferiormente, o que permite uma progressiva compreensão dos estudos em comunicação, de maneira natural, quase histórica.}

Na seção A, A produção da comunicação, Martino começa a trilhar o caminho das pesquisas na área a partir das tradicionais escolas norte americana e frankfurtiana. O autor faz uma breve retomada histórica sobre os meios de comunicação e explica que, apesar destes não terem sido inventados nos EUA, o imenso consumo de produtos midiáticos no país propiciou o surgimento das primeiras escolas de comunicação, em consequência dos primeiros estudos na área da Mass Communication Research. Martino identifica o livro Public Opinion, de Walter Lippmann como o marco dos estudos em comunicação e apresenta diferentes modelos teóricos a partir de Lasswell até chegar aos estudos sobre newsmaking e enquadramento.

A introdução à Escola de Frankfurt dá-se de forma descontraída, através do relato da visita de Martino ao Instituto de Pesquisa Social, onde surgiu esta linha de pesquisa que permanece latente nos estudos contemporâneos sobre comunicação. Introduz-se o conceito de Indústria Cultural, como estabelecida por
Adorno e Horkheimer, explora-se o pensamento de Benjamin em relação à aura e a reprodutibilidade técnica da arte, além de apresentar as teorias de Habermas sobre formação e declínio da esfera pública burguesa a partir da consolidação da imprensa e da sua posterior dependência da publicidade. É apenas neste momento que apresenta a ideologia como entendida por Marx e Engels, o que pode causar certo estranhamento inicial, mas que indica, ao seguir apresentando as ideias de Gramsci e Althusser que a crítica marxista não cessa.

Na seção B, Do Texto ao Contexto, o autor remetese à civilização grega como origem dos primeiros questionamentos sobre linguagem para mostrar como esta questão ocupa lugar privilegiado no pensamento ocidental e como a linguagem está inserida em uma relação tripla com o pensamento e a sociedade, que auxiliam na compreensão dos fenômenos da comunicação.

Apresentados alguns dos conceitos essenciais para trabalhar-se com a linguagem, Martino parte para a exploração da ciência geral das relações entre os signos e significados na construção de sentido e problematiza a diferenciação entre os termos semiologia e semiótica, a primeira normalmente relacionada à escola francesa a partir dos estudos de Saussure e a segunda relacionada à escola norte-americana de Peirce. O destaque do autor, entretanto, está em afirmar que essa diferenciação está longe de ser uma constante e que é muito mais uma questão de legitimação pelo uso do que uma diferença específica. A introdução à ciência geral das linguagens, porém, não se restringe à divisão saussuriana entre língua e fala ou à relação triádica dos signos em Peirce, como é comum aos livros de teoria da comunicação. Martino dá um passo à frente e apresenta a semiótica soviética, que conciliou o estudo das relações humanas concretas, em termos históricos e sociais, com o estudo dos signos. Continua o caminho na análise do discurso proposta por Bakhtin para o qual todo o signo é político na medida em que está ligado a condições sociais e relações de produção dentro de uma sociedade.

Assim, é possível prosseguir ao estruturalismo, iniciando pelos estudos de Barthes e as relações entre linguagem e poder, o último incorporado tanto aos discursos quanto às ações. Destaca-se o pensamento de Umberto Eco e seu esforço em fazer uma das primeiras tentativas de classificar as teorias da comunicação de massa através da divisão entre apocalípticos e integrados. Passeia-se pelo modelo de comunicação de Roman Jakobson, o estudo da cultura de massa de Edgar Morin e o poder vinculado ao saber e localizado nas tramas do 
discurso de Foucault.

Nas duas últimas seções, o sujeito é o centro da reflexão. Os estudos de recepção, por exemplo, "é um processo contínuo de atribuição de sentidos” (p. 177), dinamizada pelo diálogo entre produtor e receptor. Essa atenção ao protagonismo do sujeito rompe com a visão determinista das coisas dadas e do bem comportado. Martino sugere que "as portas para uma recepção mais ativa" (p. 183) estejam sempre abertas, pois para enfrentar os desafios dos novos tempos é necessário que essa trama seja articulada no coletivo, isso se deve porque cada vez mais estamos imersos na presença maciça de informações ou a intervenções continua dos meios de comunicação e elas certamente acentuam as conexões das culturas híbridas (Canclini, 2008). Essa hibridação cultural ganha contornos significativos com as redes de relacionamentos sociais potencializadas pelas novas tecnologias. Eis o panorama e as perspectivas das teorias da comunicação no processo de criação de significados.

A obra é um ótimo e indispensável subsídio para professores, pesquisadores, estudantes de comunicação e todos que queiram se aventurar no universo da Teoria da Comunicação. A iniciativa do autor é louvável, pois, contribui para o desenvolvimento de novas pesquisas no campo comunicacional e qualifica o debate nessa área ampla e desafiadora.

\section{REFERÊNCIAS}

CANCLINI, Néstor García. Culturas híbridas: Estratégias para entrar e sair da modernidade. São Paulo: EdUSP, 2008.

MATTELART, Armand; MATTELART, Michèle. História das teorias da comunicaşão. São Paulo: Loyola, 2007. 